\title{
An Investigation of the Relationship between Test Anxiety, Self Esteem and Academic Performance among Polytechnic Students in Nigeria
}

\author{
Olaitan W. Akinleke \\ Department of General Studies, Federal Polytechnic, \\ P.m.b. 50, Ilaro, Ogun State, Nigeria.
}

\begin{abstract}
The aim of this study was to discover how test anxiety and self esteem affect academic performance. Two hundred and fifty randomly drawn final year National Diploma (NDII) students of the Federal Polytechnic, Ilaro were involved in the study. They were given two questionnaires that took between forty and forty five minutes to complete. The study was carried out in a classroom environment during regular school hours. After collecting information from the students through questionnaires, their comprehensive Grade Point Averages (GPA) in previous year were also collected. This GPA data were then compared to the scores obtained from the questionnaires. This study discovered that overall, low anxiety students had higher GPAs than high anxiety students and that there is a positive relationship between self esteem and academic performance. The implication of the findings were that stakeholders in education should formulate policies that help students to cope with anxiety and also initiate programs that will assist the process of learning and mastering challenges as such would result in higher academic achievement.
\end{abstract}

Keywords: Test anxiety, self esteem and academic performance.

\section{INTRODUCTION}

Especially in the recent times, concern has been raised over the continuous decline in the academic performance of students in Nigeria. Research has revealed that various factors such as family socioeconomic status (Jacob \& Havey, 2005; Okafor, 2007; Akinleke, 2010), school factors (Marks, Millan \& Hillman, 2001; Win \& Miller, 2004) and social support (Quamma \& Greenberg, 1994; Calvete \& Connor-Smith, 2006) influence academic performance.

Evidently, these factors greatly affect the scholastic performance of students but equally important are certain personality factors of the students themselves. Recent debates have tried to link academic performance with issues such as the self esteem and test anxiety of the students. For instance, Fathi-Ashtiani, Ejei, Khodapanahi and Tarkhorani (2007) noted that self esteem plays an important role in the educational function of students.

The fact that education is the substratum of any society cannot be questioned as it is important to the students, parents and the community at large. For instance, it equips the students with a wholesome personality and strong leadership qualities so that they are capable of dealing with current and future challenges just $s$ it serves as a buffer against life stressors for the parents and as well as an agent promoting wealth, health and wellness for the community. It therefore becomes important to look at how anxiety and the self esteem of students influence their academic experiences. Cizek and Burg (2006) opined that among the diversity of academic experiences associated with emotions, test anxiety has a long educational history that warrants ongoing attention today just as Aryana (2001) notes that "today, self esteem is receiving increasing attention as one of the influential factors which affects student's academic achievement" (p.1)

Ndirangu, Muola, Kithuka and Nassiuma (2009) described test anxiety as "the hyper-arousal condition that results in physiological, emotional and intellectual changes that prevent the effective use of the previously learned information, while taking an examination" (p.2). According to them, test anxiety has two subcomponents: emotionality and cognition. The emotionality subcomponent suggests the physical arousal in relation to performance (Bembenutty, 2009) while the cognitive component signifies the worry that hinders attention, concentration and effective information processing (Mathews, Zeidner \& Roberts, 2006).

Seemingly, students are mechanically pressed to make high scores since their examination grades are used to admit them into higher colleges and to employ them. As a result, their yearning and anxiety increase. Remarkably, some researchers have demonstrated that the best way to tackle anxiety and to improve student performance is to increase their self esteem (Rubie, Townsend \& Moore, 2004) and that high self esteem plays important role in academic achievement, social and personal responsibility (Redenbach,1991).

Fathi-Ashtiani et al. (2007) described self esteem as a person's opinion of him/herself, that is, the extent to which an individual sees himself as capable, worthy or efficient. Aryana (2010) concludes that students who feel more confident about themselves are not apprehensive and they have higher academic achievement in contrast to those who do not have confidence in themselves. In the same vein, Naderi, Abdullah, Aizan, Sharir and Kumar (2009) noted that research has consistently shown a positive correlation between how people value themselves and the level of their academic attainments. According to them, those who feel confident, generally achieve more, while those who lack confidence in themselves achieve less. The purpose of this study is to investigate the relationship between anxiety, self esteem and academic achievement. Specifically, this study intends to determine whether these emotional and personality variables might interact to explain high achievement among the students of higher learning using a case-study analysis. 
Owayed (2005) points out that a certain degree of anxiety is generally needed to make students efficient and striving. However, it becomes detrimental if it increases beyond that degree. Individuals with low and moderate levels of anxiety do not worry and are able to concentrate on their studies (Drummond, 1996; Owayed, 2005) and they have been associated with significantly high test scores (Chapell et al., 2005). In contrast, individuals with high levels of anxiety tend to do worse (Goldman, 1991) and therefore focus on expectations of failure and the undesirable consequences of personal inadequacy (Smith, 1995).

Friedman and Bendas-Jacob (1997) observed that among factors that contribute to the development of test anxiety is self esteem. According to them, worry of suffering a reduction of the self image, particularly in the eyes of peers, leads to higher test anxiety levels. Students who felt positive about themselves had fewer sleepless nights, were friendlier and tended to perform better academically in contrast to students with a low self esteem that tended to be unhappy, less friendly and were more susceptible to depression, which were correlated with lower academic achievement (Fathi-Ashtiani et al. 2007). Generally, those with low self esteem tend to be unhappy, less sociable, more likely to use drugs and alcohol, and are more vulnerable to depression, which are all correlated with lower academic achievement (Wiggins, 1994).

Guay, Marsh, and Boiving (2003) described academic self esteem as how students do school work or feel about themselves as learners. In other words, academic self esteem refers to a student's self evaluation regarding specific academic domains or abilities (Truautwein, Ludtke, Koller, \& Baumert, 2006) and as students grow older, their academic self concept becomes more stable (Guay, et al., ibid.). Pullman and Allik (2008) discovered that high self concept significantly facilitates academic achievement. Similarly, in a study conducted to determine the role of self efficiency, self regular and self esteem in high school students' academic achievement, Amini (2004) discovers a positive and significant relationship between self esteem and academic achievement.

\section{METHOD}

\subsection{Subjects}

A random sample of 250 students (one hundred and thirteen females and one hundred and thirty seven males) of the School of Applied Science and Engineering of the Federal Polytechnic, Ilaro participated in the study. They are all in the final year of the National Diploma program (ND II). Out of the two hundred and fifty students, two hundred and thirty four completed the questionnaire, which makes a response rate of 96.8. Their mean age in years was 21.3. The Polytechnic was preferred because the researchers teach there, which makes it easier for them to access.

The Beck Anxiety Inventory, which was developed by Beck, Epstein, Brown and Steer (1998) was used to measure test anxiety among the students. It consists of 21 items that was designed in Likert's -point response format, which ranged from strongly disagree (1), disagree (2), undecided (3), agree (4) to strongly agree (5).. Each student marked (X) either of the response format (as appropriate) for each statement. The total score on the scale ranged from 20 to 65 where high scores denote high anxiety. Owayed (2005) had earlier used the scale in a study of academic achievement and its relationship with anxiety, self esteem, optimism and pessimism in Kuwaiti students. According to him, the scale has good reliability and validity coefficients. For the present study, reliability coefficient of .68 was realized.

The Rosenberg self esteem scale (1989) was used to gauge students' high or low self esteem. It consists 10 items, which was also designed in the Likert's 5-point response format. This scale is valid, reliable and one of the most popular scales for measuring self esteem in adults (Blascovich \& Tomaka, 1991). A reliability coefficient of this scale was approximated at 64 .

Based on the scores they obtained on the Beck Anxiety Inventory, students were rated to have either low or high anxiety level. In the same vein, based on the self esteem questionnaire, students were regarded to have high or low self esteem. For the purpose of this study, the researchers order all items on the anxiety scale to get a total raw score of 90 . Based on this, a median raw score of 43.72 was obtained, which denotes that students whose scores were at or below 43 were considered to have low test anxiety. In the same way, students whose scores were above 44 were considered to have high test anxiety. The same method was used for the Rosenberg self esteem questionnaire. The median raw score of 37.19 was obtained for high self esteem. Impliedly, students who score 37 or above were considered to have high self esteem while those who score below 37 were taken to have low self esteem.

Academic achievement, which was the dependent variable in this study, was assessed by considering each student's grade point average (GPA) from the previous session. The GPAs judges on the traditional (as used by the Academic Board of the school) 4.0 scale ranging from 1.00 to 4.00 . Higher grades indicate that the students performed well academically.

\section{DATA ANALYSIS}

Interaction outcomes were investigated by looking at how anxiety and self esteem affect GPA. 2(anxiety: high versus low) X 2(self esteem: high versus low) factorial analysis of variance (ANOVA) were used to test hypothesis two. The alpha level was put at .05 for hypothesis one and .01 was set for hypothesis two.

\section{RESULTS}

The following hypotheses were tested:

Ha1: Anxiety and self esteem significantly affect GPA.

Ho1: Anxiety and self esteem do not have a statistically significant effect on GPA.

Ha2: High self esteem students have a greater positive relationship to academic achievement defined by GPA.

Ho2: High self esteem students do not have a statistically significant greater positive relationship to academic achievement defined by GPA.

\subsection{Hypothesis 1}

The interaction effect of anxiety and self esteem on GPA was examined using a $2 \mathrm{X} 2$ factorial analysis of variance (ANOVA). Four group mean GPAs were compared in this analysis. They are low test anxiety (TA) and high self esteem (SE); high TA and low SE; low TA and low SE; high TA and high SE. means (with standard deviations in parentheses) for the four groups were 3.652(.3313); $3.833(.072)$; $3.095(.8276)$ and $2.816(.078)$ respectively. 
See table 1 for the Mean GPAs and standard deviations and table 2 for the ANOVA summary.

Table 1. Mean GPAs and standard deviation as a function of test anxiety and self esteem on GPA

\begin{tabular}{|c|c|c|c|c|}
\hline \multicolumn{3}{|c|}{ Mean GPAs } & \multicolumn{2}{c|}{ Mean SD } \\
\hline $\begin{array}{c}\text { Self } \\
\text { Esteem }\end{array}$ & Internal & External & Internal & External \\
\hline High & 3.652 & 3.095 & .3313 & .8276 \\
\hline Low & 3.833 & 2.816 & .072 & .078 \\
\hline $\begin{array}{l}\text { Note. The values represent mean GPAs on a scale } \\
\text { of } 1.00 \text { to 4.00 }\end{array}$ \\
\hline
\end{tabular}

Table 2. Analysis of variance as a function of test anxiety and self esteem on GPA

\begin{tabular}{|c|c|c|c|c|c|c|}
\hline Source & SS & df & MS & F & p & D \\
\hline $\begin{array}{c}\text { Self } \\
\text { esteem }\end{array}$ & .263 & 2 & .132 & .319 & .728 & .008 \\
\hline Anxiety & 3.068 & 1 & 3.068 & 7.44 & $008 * *$ & .088 \\
\hline $\begin{array}{c}\text { Self } \\
\text { esteem } \\
\text { X } \\
\text { Anxiety }\end{array}$ & 2.963 & 2 & 1.481 & 3.593 & $.032 *$ & .085 \\
\hline Error & 31.742 & 77 & .412 & & & \\
\hline Total & 37.563 & 82 & & & & \\
\hline *p<.05.**p<.01. & & & & & \\
\hline
\end{tabular}

The factorial ANOVA revealed that there was a significant interaction effect for test anxiety by self esteem on GPA $F(2,77)=3.593$, p.05. a main effect was not observed for self esteem. A closer look at the interaction reveals that marginal mean GPAs are significantly higher for internals in both high and low groups.

\subsection{Hypothesis 2}

This wanted to find out if self esteem has any significant relationship to GPA scores. A Pearson product-moment correlation was conducted in order to test this hypothesis.

Table 3. Inter-correlations between GPA, self esteem and test anxiety

\begin{tabular}{|c|c|c|c|c|}
\hline & $\begin{array}{c}\text { Self } \\
\text { Esteem }\end{array}$ & GPA & Anxiety & \\
\hline Correlates & 1 & 2 & 3 & $\mathrm{p}$ \\
\hline $\begin{array}{c}\text { Self } \\
\text { Esteem }\end{array}$ & - & - & .198 & $.036^{*}$ \\
\hline GPA & .620 & - & - & $.001^{* *}$ \\
\hline $\begin{array}{c}\text { Test } \\
\text { Anxiety }\end{array}$ & - & .309 & - & $.002^{* *}$ \\
\hline$* \mathrm{p}<.05 . * * \mathrm{p}<.01$. & & & \\
\hline
\end{tabular}

There is a statistically significant relationship between test anxiety and GPA, $r(90)=.309, \mathrm{p}<.01$. Though, the relationship may not have much practical significance since the $r$ value of .309 is the low moderate range in terms of strength of the relationship.

\section{DISCUSSION AND CONCLUSION}

This study establishes that there was a statistically significant association between anxiety and self esteem on GPA and that there is a statistically significant interaction between low level of anxiety and academic achievement.

An interesting finding is that in both low and high self esteem groups, less worried students had higher GPAs than the more worried. This discovery is in line with some previous researchers. For instance, Diaz, Glass, Arnkoff and Tanosfsky (2001) found a significant relationship between academic achievement and anxiety. Ndirangu et al. (2009) and Owayed (2005) also concluded that there is a positive relationship between high degrees of academic achievement and low anxiety. In the same vein, Aryana (2010); Fathi-Ashtiani et al. (2007) and Walter (2003) have all concluded that there is a significant relationship between self esteem and academic achievement. On the whole, this study concludes that emotional and personality factors are important and relevant in understanding the fundamental elements of academic achievement. This study is restricted to test anxiety and self esteem of students, future research may focus on analytical issues such as faculty attitudes and class treatment of students before the exam.

\section{RECOMMENDATION}

In view of the findings of this study, it could be recommended that school authorities should work out guidelines as well as develop a program that help students to cope with test anxiety. Students should be given adequate time to rest and plan for their examinations rather than last minute rush revision that may not allow them to satisfactorily prepare for their examinations.

Also, school authorities and all stakeholders in education must help students to appreciate the connection between self esteem and academic performance by initiating programs that help to grasp and subdue challenges. When students understand that one's own competence and self efficacy moderate performance, they are likely to be more diligent and persistent rather than being weak and helpless.

\section{REFERENCES}

[1] Afuwape 2003. Test taking as determinant of examination misdemeanor. Journal of Educational Studies, 3(1\&2), 32-39.

[2] Akinleke, W.O. 2012. The effects of background characteristics and school factors on college students' performance and satisfaction. Journal of Education and Practice, 3(8), 251-257.

[3] Amini, S. 2004. The role of self efficiency, self regular and self esteem in high school students' academic achievement. Tarbiat Moallem Tehran, Shaeh Kord, Iran.

[4] Aryana, M. 2010. Relationship between self esteem and academic achievement amongst pre-university students. Journal of Applied Science, 10, 2474-2477.

[5] Beck, A.T., Epstein, N., Brown, G. \& Steer, R.A. 1988. An inventory for measuring clinical anxiety: Psychometric properties. Journal of Consulting and Clinical Psychology, 56, 893-897.

[6] Bembenutty, H. 2009. Test anxiety and academic delay of gratification. College Student Journal, 43. Retrieved from http://findarticles.com/p/articles/mi.

[7] Blascovich, J.V. \& Tomaka, J. 1991. Measures of self esteem. In J.P. Robinson, P.R. Shaver \& L.S Wrightsman (Eds.). Measures of personality and social psychological attitudes (Vol.1). San Diego; Academic Press. 
[8] Calvete, H. \& Connor-Smith, J.K. 2006. Perceived social support, coping and symptoms of distress in America and Spanish students. Anxiety, Stress and Coping, 19(1), 47-65.

[9] Chapel, M.S., Blanding, Z.B., Silvestein, M.E., Takahashi, M.N.B., Newman, B., Gubi, A. \& McCain,N. 2005. Test anxiety and academic performance in undergraduate and graduate students. Journal of Educational Psychology, 97(2), 268-274.

[10] Cizek, G.J. \& Burg, S.S. 2006. Addressing test anxiety in a high-stakes environment: Strategies for classrooms and schools. Thousand Oaks, CA: Corwin Press.

[11] Diaz, R.J., Glass, C.R., Arnkoff, D.B. \& TanofskyKraff, M. 2001. Cognition, anxiety, and prediction of performance in 1st year law. Journal of Educational Psychology, 93,420-429.

[12] Drummond, R. 1966. Appraisal procedures for counselors and helping professionals. New Jersey: Prentice Hall.

[13] Fathi-Ashtiani, A., Ejei, J., Khodapanahi, M.K. \& Tarkhorani, H. 2007. Relationship between self concept, self esteem, anxiety, depression and academic achievement in adolescents. Journal of Applied Science, 7, 995-1000.

[14] Friedman, I.A. \& Bedas-Jacob, O. 1997. Measuring perceived test anxiety in adolescents: A self-report scale. Journal of Educational and Psychological Measurement, 57, 1035-1047.

[15] Goldman, L. 1991. Using tests in counseling. Pacific palisades: Good Year. Retrieved from http://www.okaforp@stjohns.edu

[16] Guay, F. Marsh, H.W., \& Boiving, M. 2003. Academic self concept and achievement: developmenmtal perspective on their causal ordering. Journal of Educational Psychology, 95, 124-136.

[17] Jacobs, N. \& Harvey, D. 2005. Do parents make a difference to children's academic achievement? Differences between parents of higher and lower achieving students. Journal of Educational Studies, 4, 431-448.

[18] Marks, G., McMillan, J \& Hillman, K. 2001. Tertiary entrance performance: The role of student background and school factors. Longitudinal Surveys of Australian Youth, 22, 11-37.

[19] Mathews, G., Zeidner, M. \& Roberts, R. 2006. Models of personality and affect for education: A review and synthesis. In Alexander, P.A. \& Winne, P.H. (Eds.) Handbook of Educational Psychology ( $2^{\text {nd }}$ ed., p.163-186). Mahwah, New Jersey: Lawrence Erlbaum Associates.

[20] Mefteh, S. 2002. The relationships between timidness (shyness), self esteem and academic achievement among middle of schools' students. University of Tarbiyat Moallem, Tehran, Iran

[21] Naderi, H., Abdullah, R., Aizan, T.H., Sharir, J. \& kumar, V. 2009. Self esteem, gender and academic achievement of undergraduate students. American Journal of Scientific Research, 3, 26-37.
[22] Nayor, F.D. 1994. Test-taking anxiety and expectancy of performance. In Olatoye, R.A., \& Afuwape, M.O. 2003. Test taking as determinant of examination misdemeanor. Journal of Educational Studies, 3(1\&2), 32-39.

[23] Ndirangu, G.W., Muola, J.M., Kithuka, M.R. \& Nassiuma, D.K. 2009. An investigation of the relationship between test anxiety and academic performance in secondary schools in Nyeri District, Kenya. Global Journal of Educational Research, 8(1\&2), 1-7.

[24] Okafor, P.C. 2007. A case study: Factors contributing to the academic achievement of low socioeconomic status students in Anambra South County, Anambra State, Nigeria. (Doctorial dissertation, St. John's University, 2007). Retrieved from http;//www.okaforp@stjohns.edu

[25] Onwayed, El-Anzi, F. 2005. Academic achievement and its relationship with anxiety, self esteem, optimism and pessimism in Kuwaiti students. Journal of Social Behavior and Personality, 13. Retrieved from http://scialert.net/abstract/

[26] Pullman, H., \& Allik, J. 2008. Relations of academic and general self esteem to school achievement Personal and Individual Differences, 45(6), 559-564.

[27] Quamma, J.P. \& Greenberg, M.T. 1994. Children's experience of life stress: The role of family social support and social problem-solving skills as protective factors. Journal of Clinical Child Psychology, 23, 295-305.

[28] Redenbach, S. 1991. Self esteem, the necessary ingredient for success. Esteem Seminar programs and publications, USA.

[29] Rosenberg, M. 1989. Society and the adolescent self image. Middletown, CT: Wesleyan University Press.

[30] Rubie, C.M., Townsend, M.A.R. \& Moore, D.W. 2004. Motivational and academic effects of cultural experiences for indigenous minority students in New Zealand. Journal of Educational Psychology, 24, 143 160.

[31] Smith, C.P. 1995. The influence on test anxiety score of stressful versus neutral conditions of test administration. Journal of Educational Psychology Measurement, 25, 135-141.

[32] Trautwein, U., Ludtke, O., Koller, O., \& Baumert, J. 2006. Self esteem, academic self concept, and achievement: How the learning environment moderates the dynamics of self concept. Journal of Personality and Social psychology, 90, 334-349.

[33] Walter, W.W. 2003. The reevaluation of the relationships among academic performance, academic achievement, social acceptance and the self esteem of third and sixth grade students. Dissertation Abstr. Int., 64, 239-244.

[34] Win, R. \& Miller, P.W. 2004. The effects of individual and school factors on University students' academic performance. Retrieved from http://www.clmr.exel.uwa.edu.au 